\title{
PENGARUH PEMBERIAN EKSTRAK DAUN CARICA PUBESCENS Lenne \& $K$. koch TERHADAP KETEBALAN EPITEL GINGIVA MENCIT BETINA YANG DIPAPAR ASAP ROKOK
}

\author{
Risma Aprinda Kristanti ${ }^{1}$ \\ ${ }^{1}$ Program Studi Pendidikan Dokter Fakultas Kedokteran dan Imu-ilmu Kesehatan \\ Universitas Islam Negeri Maulana Malik Ibrahim Malang \\ E-mail: risma.aprinda@yahoo.com
}

\begin{abstract}
ABSTRAK
Rangsangan asap rokok yang lama, dapat menyebabkan kerusakan pada bagian mukosa mulut yang terpapar, penebalan menyeluruh bagian epitel mulut termasuk epitel gingiva, hingga dapat menimbulkan bercak putih keratotik yang menandai leukoplakia dan kanker mulut. Beberapa komponen dalam tanaman $C$. pubescens terbukti memiliki aktivitas antioksidan, diantaranya adalah minyak atsiri, polifenol, dan flavanoid. Kandungan antioksidan utama dalam C.pubescens adalah vitamin C. Selain itu, kandungan flavonoid dalam C.pubescens berfungsi melindungi struktur sel dan memiliki hubungan sinergis dengan vitamin C. Tujuan penelitian ini adalah untuk mengetahui pengaruh pemberian ekstrak buah $C$. pubescens terhadap ketebalan epitel gingiva mencit betina yang dipapar asap rokok. Sebanyak 25 ekor mencit betina Mus musculus dibagi menjadi lima kelompok dan dipapar asap rokok selama 21 hari. Pada kelompok K1 sebagai kelompok kontrol negatif diberikan paparan asap rokok dan cmc, pada kelompok K2 sebagai kontrol positif diberikan paparan asap rokok dan vitamin C, kelompok K3 diberikan paparan asap rokok dan ekstrak daun C. pubescens sebanyak 0,5 gram/kgBB, kelompok K4 diberikan paparan asap rokok dan ekstrak daun C. pubescens sebanyak 1 gram/kgBB, dan pada kelompok K5 diberikan paparan asap rokok dan ekstrak daun C. pubescens sebanyak 2 gram/kgBB. Pada hari ke-22 seluruh tikus dikorbankan dan diambil jaringan gingiva. Selanjutnya pada jaringan gingiva dilakukan pengecatan menggunakan Hematoxylin Eosin (HE) untuk melihat ketebalan epitel gingiva secara histologis. Hasil penelitian menunjukkan antara keempat kelompok penelitian terdapat perbedaan yang signifikan untuk ketebalan epitel gingiva mencit betina Mus musculus, dan rerata epitel gingiva paling tebal pada kelompok K2
\end{abstract}

Kata kunci: epitel, gingiva, ekstrak, C.pubescens

\begin{abstract}
The exposure from cigarette smoke in long term can destroy oral mucous, thickening of the epithel gingival tissue, and keratotic white spot that sign leukoplakia and oral cancer. Several components in the C.pubescens leaf for example atsiri oil, polifenol, and flavonoid are kown has antioxidant acivity. The major component in C.pubescens leaf that have antioxidant activity is vitamin C. The aim of this study is to examine the effect of $C$. pubescens leaf extract to the thickness of gingival tissue from female mices that got cigarette smoke exposure. Twenty five adult female mices were devided into five group and they exposed by cigarette smoke for twenty one day. K1 group as negative control were given by $\mathrm{cmc}$, K2 group as positive control were given by $0,2 \mathrm{mg}$ vitamin $\mathrm{C}$, K3 group were given by $0,5 \mathrm{~g} / \mathrm{KgBW}$ C. pubescens extract, $\mathrm{K} 4$ group were given by $1 \mathrm{~g} / \mathrm{KgBW}$ C. pubescens extract, and $\mathrm{K} 5$ group were given by $2 \mathrm{~g} / \mathrm{KgBW}$ C. pubescens extract. At the end of $22^{\text {nd }}$ day, the mices were sacrificed and the gingival mucosa were collected for histologist preparations.

The result of this study shows that K2 group has the thickest gingival epithel layers while there is significant different among five group for the thikness gingival epithel layers.
\end{abstract}

Kata kunci: epitel, gingiva, ekstrak, C.pubescens 


\section{PENDAHULUAN}

Merokok merupakan salah satu kebiasaan yang dapat menyebabkan peningkatan stres oksidatif dalam tubuh. Asap rokok merupakan salah satu polutan yang dapat meningkatkan oksidan dalam tubuh dan merupakan polutan penyumbang radikal bebas terbesar diantara polutan lainnya. Lingkungan asap rokok dapat menyebabkan timbulnya berbagai jenis gangguan kesehatan pada perokok aktif maupun pasif [1].

Sebagian besar perokok berasal dari negara berkembang dan dari golongan sosial ekonomi rendah. Prevalensi perokok di Indonesia adalah 69\% pria dan 4\% wanita. Merokok diestimasikan 90\% menyebabkan kanker paru - paru pada pria, dan sekitar $70 \%$ pada wanita. Di negara negara industri, sekitar 56\% - 80\% merokok menyebabkan penyakit pernafasan kronis dan sekitar 22\% penyakit kardiovaskular. Dari seluruh perokok yang ada $70 \%$ yang menderita penyakit akibat merokok adalah Negara berkembang. Indonesia menduduki peringkat ke-4 jumlah perokok terbanyak di dunia dengan jumlah sekitar 141 juta orang, dengan kenaikan konsumsi rokok tertinggi di dunia (44\%). Konsumsi rokok Indonesia setiap tahun diperkirakan mencapai 199 miliar batang rokok. Akibatnya adalah kematian sebanyak 5 juta orang per tahunnya. Bila hal ini tidak dapat dicegah, maka jumlah kematian akan meningkat dua kali mendekati 10 juta orang pertahun pada tahun 2020. Tahun 2005, biaya yang harus dikeluarkan akibat penyakit terkait tembakau mencapai18,1 milyar US Dolar [2].

Merokok tidak hanya menimbulkan efek secara sistemik, tetapi juga dapat menyebabkan timbulnya kondisi patologis di rongga mulut. Tar, nikotin, dan karbonmonoksida merupakan tiga macam bahan kimia yang paling berbahaya dalam asap rokok. Berbagai penelitian terdahulu membuktikan adanya pengaruh rokok terhadap kesehatan gigi dan rongga mulut [3]; [4]. Telah banyak penelitian yang menunjukkan adanya hubungan antara merokok dan penyakit periodontal. Penelitian membuktikan bahwa pada perokok lebih banyak terjadi penyakit periodontal yang parah dan penyakit radang gingiva dibandingkan pada bukan perokok. Penelitian-penelitian terbaru menunjukkan bahwa pada perokok pasif memiliki resiko lebih tinggi sampai 1,5 kali lebih besar terkena penyakit gingiva [5].

Munculnya berbagai kondisi patologis sistemik maupun lokal dalam rongga mulut, disebabkan karena terjadinya penurunan fungsi molekul, termasuk saliva. Kerusakan komponen antioksidan saliva, diikuti dengan penurunan fungsinya, ditemukan pada beberapa kelainan di rongga mulut. Rongga mulut adalah bagian yang sangat mudah terpapar efek rokok, karena merupakan tempat terjadinya penyerapan zat hasil pembakaran rokok yang utama [6]. Komponen toksik dalam rokok dapat mengiritasi jaringan lunak rongga mulut, dan menyebabkan terjadinya infeksi mukosa, dry socket, memperlambat penyembuhan luka, memperlemah kemampuan fagositosis, menekan proliferasi osteoblas, serta dapat mengurangi asupan aliran darah ke gingiva [6]. Penyakit periodontal termasuk akumulasi plak dan kalkulus, saku periodontal, inflamasi gingiva, resesi gingiva, serta kehilangan tulang alveolar [7].

Rangsangan asap rokok yang lama, dapat menyebabkan kerusakan pada bagian mukosa mulut yang terpapar, penebalan menyeluruh bagian epitel mulut, hingga dapat menimbulkan bercak putih keratotik yang menandai leukoplakia dan kanker mulut [7]. Iritasi kronis bahan karsinogen tar menyebabkan perubahan awal struktur dasar epitel mukosa mulut, salah satunya 
adalah keratosis atau penebalan epitel, bahkan dapat menyebabkan displasia epitel yang mengalami keganasan.

Keseimbangan antara SOR dan antioksidan sangat diperlukan untuk mencegah terjadinya stres oksidatif [8]. Berbagai jenis antioksidan seperti glutation (GSH), melatonin, vitamin C, vitamin E, $\beta$-karoten, koenzim Q10, likopen, flavonoid, isoflavon antosianin, asam lipoat/alpha lipoic acid (ALA) serta substansi lainnya dapat diperoleh dari makanan maupun suplemen [9]; [10]. Kerusakan oksidatif dapat dihalangi oleh senyawa antioksidan yang terdapat dalam tumbuhan, melalui reduksi dengan radikal bebas, membentuk kelat dengan senyawa logam katalitik, dan menangkap oksigen [11].

Salah satu usaha pencarian senyawa antioksidan dapat dilakukan dengan eksplorasi senyawa aktif dari tanaman ataupun hewan ciptaan Allah SWT. Allah SWT berfirman dalam surat Al An'am ayat 99 :

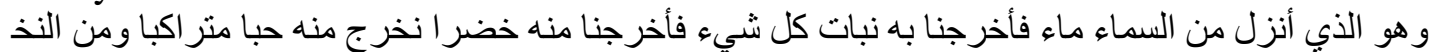

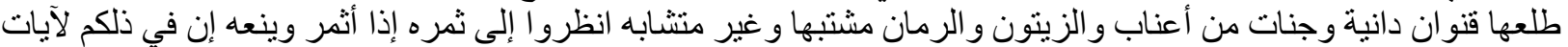
لقوم يؤمنون

Artinya: "Dan Dialah yang menurunkan air hujan dari langit, lalu kami tumbuhkan dengan air itu segala macam tumbuh-tumbuhan, maka Kami keluarkan dari tumbuh-tumbuhan itu tanaman yang menghijau, Kami keluarkan dari tanaman yang menghijau itu butir yang banyak; dan dari mayang kurma mengurai tangkai-tangkai yang menjulai, dan kebun-kebun anggur, dan (Kami keluarkan pula) zaitun dan delima yang serupa dan yang tidak serupa. Perhatikanlah buahnya di waktu pohonnya berbuah, dan (perhatikan pulalah) kematangannya. Sesungguhnya pada yang demikian itu ada tanda-tanda (kekuasaan Allah) bagi orang-orang yang berimam [12].

Carica pubescens Lenne \& K. Koch (C. Pubescens) merupakan pohon kecil atau perdu yang tidak berkayu, mirip dengan Carica papaya tetapi mempunyai cabang yang lebih banyak dan ukuran semua bagian tanaman lebih kecil [13]. Karakter morfologi, kapasitas antioksidan, dan analisis pola pita protein terhadap $C$. pubescens telah dilakukan [14], akan tetapi lebih lanjut mengenai pemanfaatan senyawa aktif untuk bahan makanan atau suplemen antioksidan belum banyak diteliti.

Beberapa komponen dalam tanaman $C$. pubescens terbukti memiliki aktivitas antioksidan, diantaranya adalah minyak atsiri, polifenol, dan flavanoid. Kandungan antioksidan utama dalam C.pubescens adalah vitamin C. Selain itu, kandungan flavonoid dalam C.pubescens berfungsi melindungi struktur sel, memiliki hubungan sinergis dengan vitamin $\mathrm{C}$ (meningkatkan efektivitas vitamin C), mencegah keropos tulang, antibiotik, dan sebagai antiinflamasi [15]; [16].

Vitamin C merupakan laktosa dengan enam rantai karbon yang disintesis dari glukosa di dalam hati oleh sebagian mamalia selain manusia, karena manusia tidak memiliki enzim gulonolactone oxidase yang penting untuk sintesis asam askorbat. Vitamin $\mathrm{C}$ mampu memberikan elektron dan mereduksi agen karena bentuk fisiologi dan biokimianya. Vitamin $\mathrm{C}$ menyumbangkan dua elektronnya dari rantai ganda antara dua dan tiga molekul karbon dari enam molekul karbon [17]. Dijelaskan pula bahwa, vitamin C disebut sebagai antioksidan karena dengan elektron yang didonorkan itu dapat mencegah terbentuknya senyawa lain dari proses oksidasi dengan melepaskan satu rantai karbon. Namun, setelah memberikan elektron pada radikal bebas, vitamin $\mathrm{C}$ akan teroksidasi menjadi semidehydroascorbut acid atau radikal ascorbyl yang relatif stabil. Sifat inilah yang mungkin menjadikannya sebagai antioksidan atau dengan kata lain bahwa asam askorbat dapat bereaksi dengan radikal bebas, reaksi tersebut dapat 
mereduksi radikal bebas yang reaktif menjadi tidak reaktif. Radikal bebas yang mengalami reduksi dari yang reaktif menjadi tidak reaktif disebut scavenger atau squencsing. Oleh karena itu asam askorbat baik untuk radikal bebas scavenger karena sifat kimianya.

Berdasarkan uraian di atas peneliti beranggapan bahwa penebalan epitel akibat paparan asap rokok dapat dicegah dengan pemberian ektsrak $C$. pubescens yang merupakan sumber dari vitamin $\mathrm{C}$ dimana vitamin $\mathrm{C}$ ini erat kaitannya dengan aktivitas antioksidan. Antioksidan vitamin $\mathrm{C}$ yang terkandung di dalam ekstrak C.pubescens diharapkan dapat meminimalisir radikal bebas asap rokok yang memapar mukosa rongga mulut sehingga radang mukosa rongga dapat dicegah dengan ditandai berkurangnya ketebalan epitel gingiva.

\section{METODE PENELITIAN}

Penelitian ini tergolong penelitian eksperimental laboratoris, dengan menggunakan rancangan penelitian post test only control group design. Penelitian dilakukan di Laboratorium Biosistem Jurusan Biologi UIN Maulana Malik Ibrahim Malang untuk pemeliharaan dan perlakuan hewan coba, Laboratorium Fisiologi Hewan Jurusan Biologi UIN Maulana Malik Ibrahim Malang untuk pengamatan histologi, dan Laboratorium Patologi Anatomi RS Syaiful Anwar Malang untuk pembuatan preparat histologi.

\section{Sampel}

Sampel yang digunakan dalam penelitian ini adalah mencit betina Mus musculus sebanyak 25 ekor, berusia 8-10 minggu dengan berat 20-25 gram, dalam keadaan sehat dan belum pernah digunakan untuk penelitian.

Subyek penelitian dibagi dalam lima kelompok secara random, kelompok I (K1) sebagai kontrol negatif adalah kelompok yang diberi paparan asap rokok dan mendapat CMC, kelompok II (K2) sebagai kontrol positif adalah kelompok yang diberi paparan asap rokok dan mendapat terapi vitamin C, kelompok III (K3), kelompok IV (K4), dan kelompok V (K5) adalah kelompok yang diberi paparan asap rokok dan mendapat ekstrak daun $C$. pubescens dengan sebesar 0,5 gram $/ \mathrm{kgBB}, 1$ gram $/ \mathrm{kgBB}$, dan 2 gram $/ \mathrm{kgBB}$.

\section{Paparan Asap Rokok}

Paparan asap rokok diberikan sebanyak 1 batang rokok setiap kandang, pada satu kandang ditempatkan 5 mencit pada saat perlakuan paparan asap rokok. Pada saat perlakuan, kandang ditutup dengan plastik tebal dan diberi 2 lubang, 1 lubang untuk memasukkan rokok ke dalam kandang, dan lubang lainnya untuk aliran udara. Pangkal rokok dihubungkan dengan spuit melalui selang yang memiliki diameter sama dengan diameter rokok, dan asap rokok dihembuskan melalui dorongan dari spuit. Paparan asap rokok diberikan selama 21 hari.

\section{Pemberian Ekstrak C. Pubescens}

Ekstrak daun $C$. pubescens diberikan per sonde pada mencit betina kelompok K3, K4, dan $\mathrm{K} 5$, dengan dosis tunggal yaitu 1 kali pemberian sebanyak 0,5 gram $/ \mathrm{kgBB}$ untuk kelompok $\mathrm{K} 3$, 1 gram/kgBB untuk kelompok K4, dan 2 gram/kgBB untuk kelompok K5 setiap hari selama 21 hari. Selama penelitian, mencit diperlakukan sebaik-baiknya, diusahakan agar bebas stres, leluasa bergerak, serta diberikan makanan dan minuman setiap hari secara ad libitum. 
Journal of Islamic Medicine

Volume 1(1) (2017), Pages 48-58

\section{Pengambilan Data}

Pada hari ke-22, semua mencit dikorbankan dan diambil jaringan mukosa gingiva untuk dibuat sediaan histologis. Setelah sediaan histologis selesai dibuat, dilakukan pengukuran ketebalan epitel gingiva menggunakan micrometer grid. Data yang didapat diuji normalitas dengan Kolmogorov-Smirnov. Untuk melihat perbedaan ketebalan epitel antar kelompok dilakukan Uji Games-Howell.

\section{HASIL PENELITIAN}

Berdasarkan penelitian yang telah dilakukan, diperoleh hasil rata-rata ketebalan epitel gingiva mencit pada masing-masing kelompok sebagai berikut:

Tabel 1. Nilai rerata (mean) dan simpang baku (SD) ketebalan epitel gingiva mencit pada kelompok K1, K2, K3, K4 dan K5

\begin{tabular}{|c|c|c|}
\hline Kelompok & N & Mean dan SD \\
\hline K1 & 4 & $27,35 \pm 7,73$ \\
K2 & 4 & $30,13 \pm 5,64$ \\
K3 & 4 & $17,46 \pm 1,95$ \\
K4 & 4 & $18,89 \pm 5,80$ \\
K5 & 4 & $22,18 \pm 2,29$ \\
\hline Total & 20 & $23,20 \pm 6,79$ \\
\hline
\end{tabular}

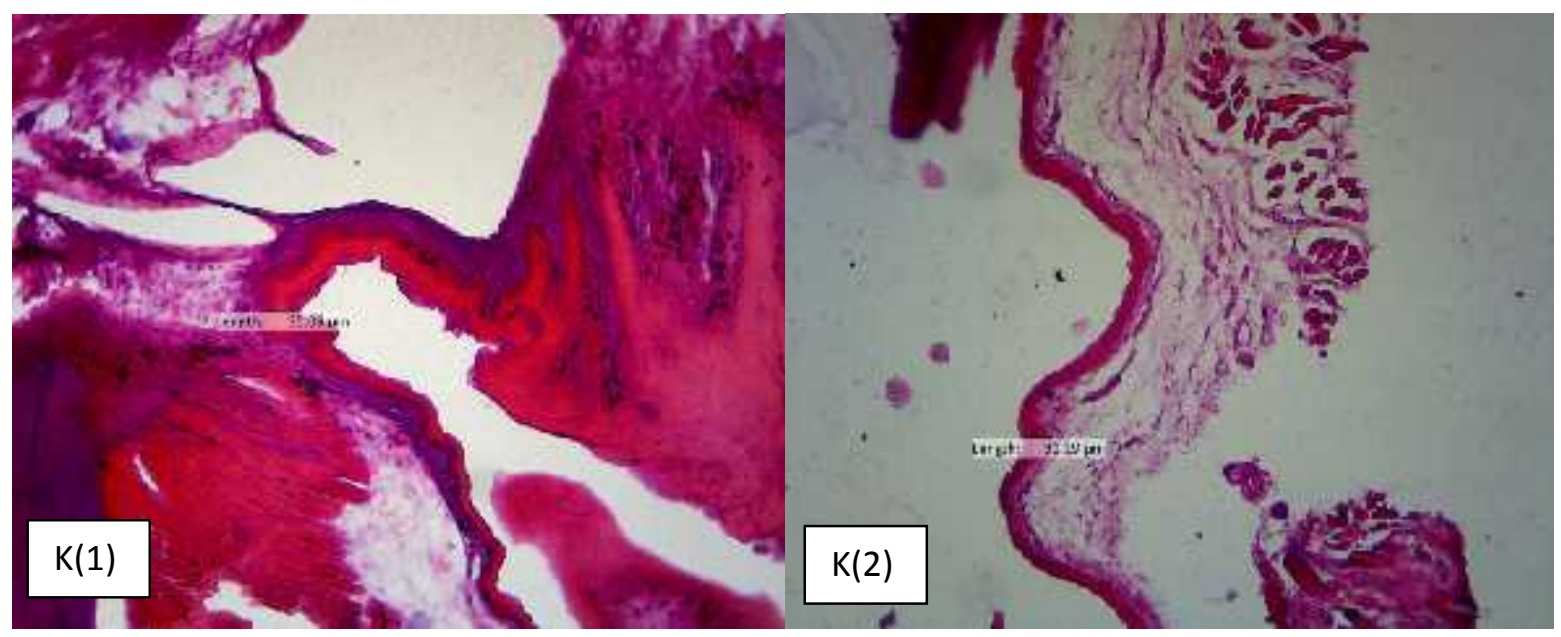




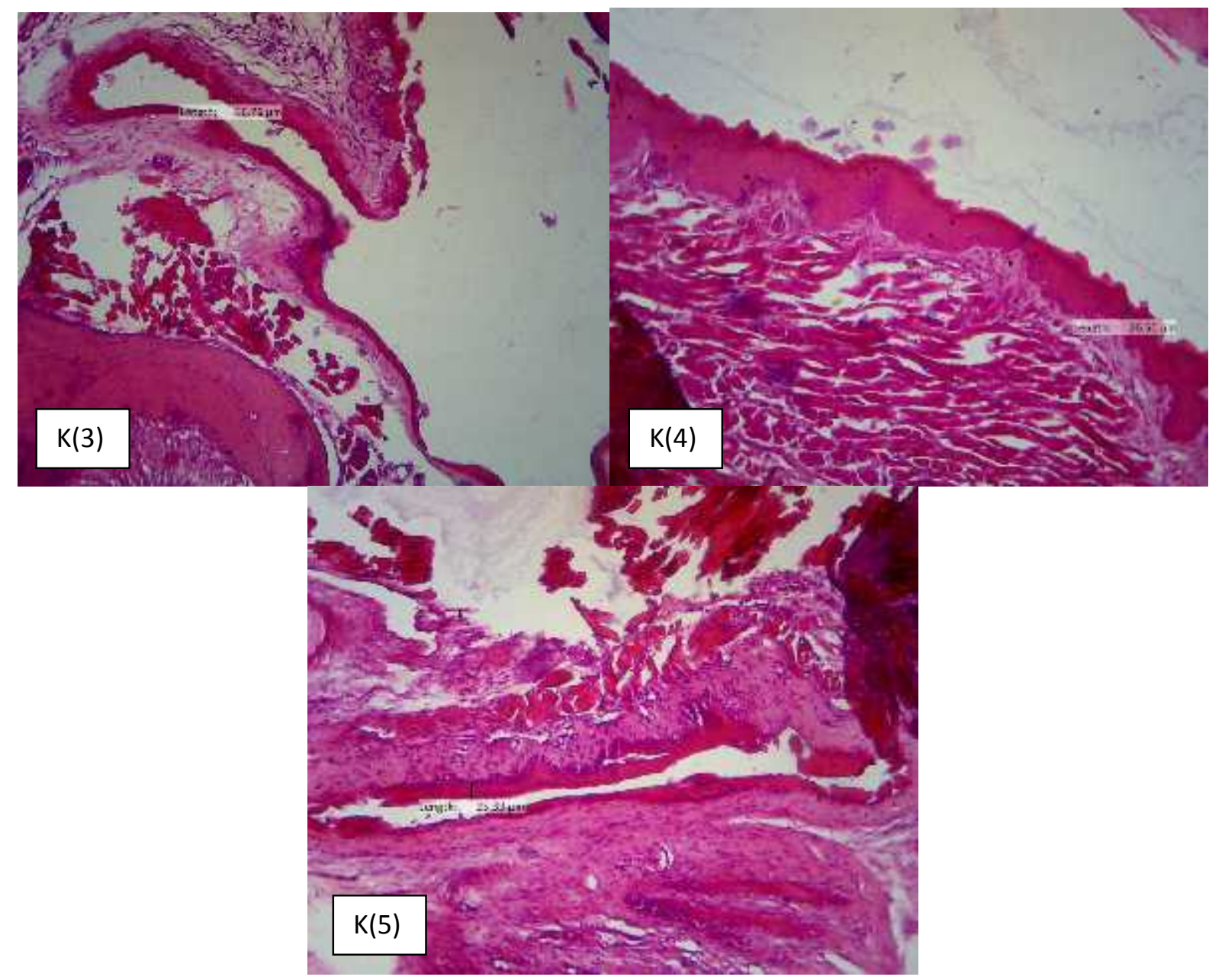

Gambar 1. Epitel Gingiva dengan pewarnaan HE. Epitel gingiva dilihat dengan perbesaran 100x menggunakan mikroskop mikrofoto olympus perbesaran 100x serta software pengolahan gambar Image Raster3. K(1) paparan rokok+CMC, $\mathrm{K}(2)$ paparan rokok+vitamin C $0,2 \mathrm{mg}, \mathrm{K}(3)$ paparan rokok+ekstrak C.pubescens $0,5 \mathrm{~g} / \mathrm{KgBB}, \mathrm{K}(4)$ paparan rokok+ekstrak C.pubescens $1 \mathrm{~g} / \mathrm{KgBB}$, dan $\mathrm{K}(5)$ paparan rokok+ekstrak C.pubescens $2 \mathrm{~g} / \mathrm{KgBB}$.

Data terlebih dahulu diuji normalitas menggunakan Kolmogorov-smirnov dan menunjukkan $(\mathrm{p}>0,05)$ sehingga dapat disimpulkan bahwa data berdistribusi normal, selanjutnya dilakukan uji homogenitas menggunakan uji Levene test, setelah data diuji menunjukkan ( $>0,05)$ yang berarti data homogen, selanjutnya untuk mengetahui beda variabel tebal epitel gingiva antar kelompok dilakukan ANOVA Test. Dari hasil ANOVA Test didapatkan bahwa ketebalan epitel antar kelompok berbeda secara bermakna dengan $\mathrm{p}=0,015(<0,05)$

Untuk mengetahui antar kelompok mana yang berbeda, dengan data berdistribusi normal dan variasi antar kelompok homogen, dilanjutkan dengan Uji LSD. Hasil uji dapat dilihat pada Tabel 2 berikut: 
Journal of Islamic Medicine

Volume 1(1) (2017), Pages 50-60

Tabel 2. Hasil uji beda LSD ketebalan epitel gingiva pada kelompok K1, K2, K3, K4 dan K5

\begin{tabular}{|l|l|l|}
\hline Kelompok & $\mathbf{P}$ & Keterangan \\
\hline K1 dan K2 & 0,460 & Tidak signifikan \\
K1 dan K3 & 0,016 & Signifikan \\
K1 dan K4 & 0,035 & Signifikan \\
K1 dan K5 & 0,178 & Tidak signifikan \\
K2 dan K3 & 0,004 & Signifikan \\
K2 dan K4 & 0,008 & Signifikan \\
K2 dan K5 & 0,046 & Signifikan \\
K3 dan K4 & 0,702 & Tidak signifikan \\
K3 dan K5 & 0,217 & Tidak signifikan \\
K4 dan K5 & 0,383 & Tidak signifikan \\
& & \\
\hline
\end{tabular}

Tabel di atas menunjukkan bahwa untuk kelompok K1-K3, K1-K4, K2-K3, K2-K4, K2K5 terdapat perbedaan yang signifikan untuk ketebalan epitel gingiva antar kelompok, sedangkan untuk kelompok K1-K2, K1-K5, K3-K4, K3-K5, K4-K5 tidak terdapat perbedaan yang signifikan.

\section{DISKUSI}

Carica pubescens Lenne \& K. Koch (C.pubescens) merupakan salah satu tanaman khas dataran tinggi di Indonesia dengan kandungan Vitamin $\mathrm{C}$ tinggi yang berpotensi sebagai bahan alami antioksidan. Di Indonesia, C. pubescens dapat dijumpai di Dataran Tinggi Dieng, Jawa Tengah dan di Cangar, Batu. Carica pubescens Lenne \& K. Koch merupakan spesies yang beradaptasi di tempat dengan ketinggian 1.400 - 2.400 meter di atas permukaan laut (dpl), temperatur rendah, dan curah hujan tinggi.

Carica pubescens Lenne \& K. Koch mempunyai banyak manfaat dalam kehidupan sehari-hari. Hasil penelitian [18] menunjukkan teridentifikasinya 19 senyawa fenol pada buah $C$. pubescens yang tumbuh di Chili. Buah $C$. pubescens mengandung zat antioksidan yang mampu menangkal bahaya radikal bebas dan mengandung enzim pencernaan yang meningkatkan kerja alat pencernaan, absorbsi nutrien, mengurangi stress pencernaan, menjaga $\mathrm{pH}$, menjaga kesehatan usus serta menyeimbangkan enzim-enzim alami tubuh [19]. C. pubescens merupakan sumber kalsium, gula, vitamin A dan C [20] dalam [21]. Vitamin C berperan dalam memperkuat dinding pembuluh darah, membantu penyembuhan luka, menurunkan tingkat stress, serta meningkatkan daya tahan tubuh dalam melawan infeksi. Oksidasi vitamin $\mathrm{C}$ dengan kofaktor $\mathrm{Fe}^{2+}$ menyebabkan dikeluarkannya sejumlah anion radikal oksigen superoksida $\left(\mathrm{O}^{2-}\right)$ [22]. Adanya senyawa-senyawa tersebut dapat memungkinkan C.pubescens dapat digunakan sebagai obat herbal yang dapat meningkatkan kecepatan regenerasi epitel. 
Penelitian ini bertujuan mengkaji lebih dalam tentang pengaruh pemberian ekstrak C.pubescens yang berasal dari daerah Cangar terhadap ketebalan epitel gingiva pada mencit betina (Mus musculus) yang dipapar asap rokok.

Penelitian ini merupakan penelitian eksperimental laboratoris yang memenuhi kriteria sebagai penelitian eksperimen murni (true experiment). Perlakuan terhadap sampel penelitian dilakukan pada ruangan yang telah tersedia dan pemeriksaan terhadap variabel yang diukur dilakukan di laboratorium [23].

Rancangan penelitian yang digunakan adalah post test only control group design karena hewan coba dibagi menjadi 5 kelompok menggunakan teknik alokasi random dan data variabel tergantung untuk masing-masing sampel diperoleh hanya setelah perlakuan atau tidak dilakukan pengambilan data variabel tergantung sebelum perlakuan [23].

Hasil analisa deskriptif menunjukkan bahwa rerata ketebalan epitel gingiva untuk kelompok yang diberi paparan asap rokok adalah $27,35 \mu \mathrm{m}$, untuk kelompok yang diberi paparan asap rokok dan terapi vitamin $C$ adalah $30,13 \mu \mathrm{m}$, untuk kelompok yang diberi paparan asap rokok dan ekstrak C.pubescens 0,5 gram adalah $17,46 \mu \mathrm{m}$, untuk kelompok yang diberi paparan asap rokok dan ekstrak C.pubescens 1 gram adalah $18,89 \mu \mathrm{m}$, dan untuk kelompok yang diberi paparan asap rokok dan ekstrak C.pubescens 2 gram adalah 22,18 $\mu \mathrm{m}$. Hal ini menunjukkan bahwa epitel gingiva yang paling tebal ada pada kelompok yang diberi paparan asap rokok dan terapi vitamin $\mathrm{C}$, sedangkan rata-rata epitel gingiva yang paling tipis ada pada kelompok yang diberi paparan asap rokok dan terapi ekstrak C. pubescens 0,5 gram. Penelitian [24] menyebutkan bahwa bila vitamin $\mathrm{C}$ bekerja sendiri kurang mampu memberikan perbedaan, supaya vitamin $\mathrm{C}$ bisa berperan secara optimal dalam menangkal radikal bebas, sebaiknya vitamin $C$ bekerja sama dengan vitamin $E$. Hal ini dikarenakan vitamin $C$ bekerja secara sinergis dengan vitamin $\mathrm{E}$ sebagai antioksidan dengan menangkap radikal bebas, vitamin $\mathrm{E}$ meyumbangkan satu elektronnya kepada radikal yang kemudian berubah menjadi vitamin $\mathrm{E}$ radikal dan selanjutnya akan distabilkan oleh vitamin C. Vitamin C yang bersifat radikal selanjutnya akan berubah menjadi stabil kembali oleh enzim antioksidan. Sedangkan ekstrak daun C.pubescens dosis 0,5 gram ternyata paling efektif dalam mengurangi penebalan epitel gingiva yang disebabkan oleh keradangan akibat paparan asap rokok. Hal ini serupa dengan penelitian [25] dimana ekstrak yang lebih tinggi dosisnya memberikan hasil yang kurang efektif, disebabkan karena kandungan antioksidan yang banyak pada esktrak $C$. pubescens berubah menjadi prooksidan karena hasil interaksinya dengan oksidan yang berasal dari paparan asap rokok.

Sedangkan dari hasil Uji ANOVA diperoleh hasil ada perbedaan bermakna ketebalan epitel gingiva antar kelompok. Antara kelompok yang dipapar asap rokok dengan kelompok yang dipapar asap rokok dan mendapat terapi vitamin $\mathrm{C}$ tidak terdapat perbedaan yang signifikan, hal ini bisa disebabkan karena bila vitamin $\mathrm{C}$ bekerja sendiri kurang mampu memberikan perbedaan, supaya vitamin $\mathrm{C}$ bisa berperan secara optimal dalam menangkal radikal bebas, sebaiknya vitamin $\mathrm{C}$ bekerja sama dengan vitamin $\mathrm{E}$. Hal ini dikarenakan vitamin $\mathrm{C}$ bekerja secara sinergis dengan vitamin $\mathrm{E}$ sebagai antioksidan dengan menangkap radikal bebas, vitamin $\mathrm{E}$ meyumbangkan satu elektronnya kepada radikal yang kemudian berubah menjadi vitamin $\mathrm{E}$ radikal dan selanjutnya akan distabilkan oleh vitamin $\mathrm{C}$. Vitamin $\mathrm{C}$ yang bersifat radikal selanjutnya akan berubah menjadi stabil kembali oleh enzim antioksidan. Antara kelompok yang dipapar asap rokok dengan kelompok yang dipapar asap rokok dan diterapi ekstrak C.pubescens dosis 2 gram juga memberikan hasil tidak signifikan yang dapat disebabkan 
karena kandungan antioksidan yang banyak atau di atas dosis optimal pada esktrak C.pubescens berubah menjadi prooksidan karena hasil interaksinya dengan oksidan yang berasal dari paparan asap rokok. Sedangkan hasil yang tidak signifikan antara kelompok yang dipapar asap rokok dan diterapi dengan ekstrak C.pubescens 0,5 gram dengan kelompok yang diterapi ekstrak 1 gram menunjukkan bahwa ekstrak C.pubescens dapat memberikan hasil optimal dengan rentang dosis antara 0,5 sampai 1 gram. C. pubescens mengandung zat antioksidan yang mampu menangkal bahaya radikal bebas dan mengandung enzim pencernaan yang meningkatkan kerja alat pencernaan, absorbsi nutrien, mengurangi stress pencernaan, menjaga $\mathrm{pH}$, menjaga kesehatan usus serta menyeimbangkan enzim-enzim alami tubuh [19]. Vitamin C berperan dalam memperkuat dinding pembuluh darah, membantu penyembuhan luka, menurunkan tingkat stress, serta meningkatkan daya tahan tubuh dalam melawan infeksi. Oksidasi vitamin $\mathrm{C}$ dengan kofaktor $\mathrm{Fe}^{2+}$ menyebabkan dikeluarkannya sejumlah anion radikal oksigen superoksida $\left(\mathrm{O}^{2-}\right)$ [22].

\section{KESIMPULAN}

Pada penelitian ini, pemberian ekstrak daun $C$. pubescens dengan dosis bervariasi dapat mempengaruhi ketebalan epitel gingiva pada mencit betina Mus musculus yang dipapar asap rokok

\section{DAFTAR PUSTAKA}

[1]. Ahsan A, Wiyono, Soerojo W, Wibisana W. 2009. Dampak Tembakau dan Pengendaliannya di Indonesia. Jakarta: Lembaga Demografi FEUI. Hal 4-80

[2]. Gondodiputro S. 2007. Bahaya Tembakau Dan Bentuk-Bentuk Sediaan Tembakau. Bagian Ilmu Kesehatan Masyarakat Fakultas Kedokteran Universitas Padjadjaran. Bandung.

[3]. Warnakulasuriya S., Dietrich T., Bornstein M., Peidró E., Preshaw P., Walter C., Wennström J., and Bergström J. 2010. Oral Health Risks Of Tobacco Use And Effects Of Cessation. International Dental Journal. Vol.60:7-30.

[4]. Mullally, BH. 2004. The Influence of Tobacco Smoking on the Onset of Periodontitis in Young Persons. Tob Induc Dis. 2 (1) 6.

[5]. Ruslan G. Efek Merokok Terhadap Rongga Mulut. Available at: File://G:/Cermin\%20 Dunia\%20 Kedokteran.htm. Accessed March 28, 2006

[6]. Aditama TY. Rokok dan Kesehatan. Jakarta: UI Press, 1997: 17-25.

[7]. Sham A., Cheung L., Jin L., and Corbet E. 2003. The Effects Of Tobacco Use On Oral Health. Hong Kong Med J. Vol.9 : 271-7

[8]. Gupta, S., Choi, A., Yu, H.Y., Czerniak, S.M., Holick, E.A., Paolella, L.J., Agarwal, A., Combelles, C.M.H. 2011. Fluctuations in Total Antioxidant Capacity, Catalase Activity, and Hydrogen Peroxide Levels of Follicular Fluid During Bovine Folliculogenesis. Reproduction, Fertility and Development. 23(5): 673-680.

[9]. Winarsi, H. 2007. Antioksidan Alami dan Radikal Bebas: Potensi dan Aplikasinya dalam Kesehatan. Yogyakarta: Penerbit Kanisius.

[10]. Hamid AA, Aiyelaagbe OO, Usman LA, Ameen OM, and Lawal A. Antioxidants: It's Medicinal And Pharmacological Applications. African Journal of Pure and Applied Chemistry Vol.4(8): 142-151, 
Journal of Islamic Medicine

Volume 1(1) (2017), Pages 53-63

[11]. Purboyo A. 2009. Efek Antioksidan Ekstrak Etanol Daun Jambu Psidium guava L. Pada Kelinci Yang Dibebani Glukosa. Dissertation.Surakarta

[12]. QS. Al An'am:99

[13]. Verheij, E.W.M dan R.E. Coronel. 1997. Prosea Sumber Daya Nabati Asia Tenggara \& Buah-Buahan Yang Dapat Dimakan. Terjemahan S.Somaatdja. Gramedia Pustaka Utama. Jakarta.

[14]. Laily, AN. 2011. Karakterisasi Carica pubescens Lenne \& K.koch berdasarkan Morfologi, Kapasitas Antioksidan, dan Pola Pita Protein di Dataran Tinggi Dieng. Tesis Universitas Sebelas Maret Surakarta

[15]. Ahkam, MS, 2008. Obat Alternatif: Sarang Semut Penakluk Penyakit Maut. www.sarangsemut.50webs.com

[16]. Hidayat, S. 2001. Prospek Pepaya Gunung (Carica Pubescens) dari Sikunang, Pegunungan Dieng, Wonosobo. Prosiding Seminar Sehari: Menggali Potensi dan Meningkatkan Prospek Tanaman Hortikultura Menuju Ketahanan Pangan. Pusat Konservasi Tumbuhan Kebun Raya Bogor-LIPI, Bogor.

[17]. Padayatty SJ, Katz A, Wang Y, Eck P, Kwon O, Lee JH, et al. 2003. Vitamin C as an antioxidant: Evaluation of its role in disease prevention. Journal of American College of Nutrition, Maryland. 22:p.18-35.

[18]. Simirgiotis, MJ. 2009. Identification of phenolic compound from the fruits of the mountain Papaya Vasconcellea pubscensa. Dc. Grown In Chile by Liquid Chromatography-uvDetection-Mass Spectrometry.Journal Food Chemistry.Vol 115 (2).

[19]. Rock W, Red. 2009. Product Review-Wild Mountain Papaya Extract http://www.associatedcontent.com/article/1987516product_review_wild_mountain_papa ya.html (Diakses 15 Agustus 2016)

[20]. Hidayat, S. 2001. Prospek Pepaya Gunung (Carica Pubescens) dari Sikunang, Pegunungan Dieng, Wonosobo. Prosiding Seminar Sehari: Menggali Potensi dan Meningkatkan Prospek Tanaman Hortikultura Menuju Ketahanan Pangan. Pusat Konservasi Tumbuhan Kebun Raya Bogor-LIPI, Bogor.

[21]. Wikipedia. 2011. Pepaya Gunung. http://id.wikipedia.org/wiki/index [10 Februari 2011].

[22]. Kusyati, E. 2010. Pengaruh Suplementasi Vitamin C Terhadap Jumlah Sel Fibroblas Di Sekitar Luka Insisi Pada Tikus Usia Tua. Tesis Program Pascasarjana Universitas Diponegoro Semarang

[23]. Zainuddin, M. 2000. Metodologi Penelitian. Surabaya: Pasca Sarjana Unair

[24]. Christijanti W, Utami NR, dan Iswara A. 2010. Efek Pemberian Antioksidan Vitamin C dan E Terhadap Kualitas Spermatozoa Tikus Putih Terpapar Allethrin. Biosaintifika. Vol. 2 No. 1

[25]. Suryani N, Endang T, Aulanni'am. 2013. Pengaruh Ekstrak Metanol Biji Mahoni terhadap Peningkatan Kadar Insulin, Penurunan Ekspresi TNF- $\alpha$ dan Perbaikan Jaringan Pankreas Tikus Diabetes. Jurnal Kedokteran Brawijaya. Vol. 27 No. 3 
Journal of Islamic Medicine

Volume 1(1) (2017), Pages 54-64 